\title{
Was bedeuten 12 Euro Mindestlohn für den Arbeitsmarkt?
}

Bereits der Einführung des Mindestlohns zum 1.1.2015 ist eine Debatte über Tarifautonomie und Beschäftigungseffekte vorausgegangen. In der Ex-post-Betrachtung lässt sich feststellen, dass die negativen Beschäftigungsverhältnisse im Wesentlichen ausgeblieben sind. Nun hat die Ampelregierung die politisch bestimmte Erhöhung des Mindestlohns auf 12 Euro beschlossen. Es stellt sich die Frage, ob diese deutliche Anhebung den Mindestlohn auf eine Höhe setzt, die sozialpolitische Risiken in sich birgt und zu Arbeitsplatzverlusten im Niedriglohnbereich führen wird.

Eine höhere Reichweite und heterogene Ausgangslagen erschweren die Vorhersage von Beschäftigungseffekten

Nicole Gürtzgen, IAB Nürnberg; Universität Regensburg.

12 Euro Mindestlohn: neue Erwartungen und alte Hürden

Alexandra Fedorets, DIW Berlin.

Der Mindestlohn von 12 Euro kommt - die sozialpolitischen Risiken bleiben

Andreas Knabe, Otto-von Guericke-Universität Magdeburg.

Ronnie Schöb, Freie Universität Berlin.

Marcel Thum, Technische Universität Dresden; ifo Institut, Dresden.

Sprung auf 12 Euro Mindestlohn: Einschränkung der Tarifautonomie und gewagtes Wirtschaftsexperiment

Helena Bach, Institut der deutschen Wirtschaft (IW), Köln.

Christoph Schröder, Institut der deutschen Wirtschaft (IW), Köln.

Die „Harmonie der Täuschungen“ muss enden, damit Politikberatung glaubwürdiger wird Arne Heise, Universität Hamburg.

Toralf Pusch, Wirtschafts- und Sozialwissenschaftliches Institut (WSI) der Hans-Böckler-Stiftung, Düsseldorf.

Title: What Does a 12 Euro Minimum Wage Mean for the Labour Market?

Abstract: The introduction of the minimum wage on 1 January 2015 was preceded by a lively debate on collective bargaining autonomy and employment effects. In an expost analysis, it appears that the negative employment effects have essentially failed to materialise. Now the German "traffic light" coalition government has decided on an increase of the minimum wage of 12 euros. The question now is whether this significant increase will set the minimum wage at a level that entails socio-political risks and will lead to job losses in the low-wage sector.

JEL Classification: J01, J20, J31, J38 